\title{
A bélendometriosis miatt végzett mütétek hatása a fertilitásra
}

\author{
Brubel Réka dr. ${ }^{1}$ - Dobó Noémi dr. ${ }^{1}$ - Csibi Noémi dr. ${ }^{1}$ \\ Kövesdi Annamária dr. ${ }^{2}$ - Máté Szabolcs dr. ${ }^{1}$ - Ács Nándor dr. ${ }^{1}$ \\ Lukovich Péter dr. ${ }^{3}$. Murber Ákos dr. ${ }^{1}$. Bokor Attila dr. ${ }^{1}$
}

\author{
${ }^{1}$ Semmelweis Egyetem, Általános Orvostudományi Kar, Szülészeti és Nőgyógyászati Klinika, Budapest \\ ${ }^{2}$ Semmelweis Egyetem, Általános Orvostudományi Kar, Laboratóriumi Medicina Intézet, Budapest \\ ${ }^{3}$ Szent János Kórház, Sebészeti Osztály, Budapest
}

\begin{abstract}
Bevezetés: Bélendometriosisról beszélünk abban az esetben, ha az endometriumhoz hasonló szövet infiltrálja a bélsubserosát, illetve eléri a subserosus neurovascularis plexust. A colorectalis endometriosis miatt végzett mútétek hatása az infertilitásra és a terhesség kiviselésére nem minden kétséget kizáróan igazolt.

Célkitüzés: A Klinikánkon bélendometriosis miatt végzett idegkímélő anterior reszekción átesett betegek fertilitási adatait vizsgáltuk egy prospektíven létrehozott adatbázis segítségével.

Módszer: 2009 és 2017 között 121, bélendometriosis miatt megoperált beteg teherbe esési szándékát, a teherbe esés módját, annak sikerességét, a terhességi kórképek előfordulását és a szülésvezetés módját vizsgáltuk.

Statisztikai analizis: Az endometriosis és a terhességi kórképek elöfordulása közti összefüggést $\chi^{2}$-próbával és Fisheregzakt teszttel vizsgáltuk, és meghatároztuk az esélyhányadost (OR) és 95\%-os konfidenciaintervallumát (CI). Az eredményt $\mathrm{p}<0,05$ esetén tekintettük szignifikánsnak.

Eredmények: Klinikánkon 121, bélendometriosis miatt megoperált beteg közül 48-an (39,6\%) estek teherbe, 37-en $(30,5 \%)$ mesterséges megtermékenyítés segítségével. A kontrollcsoportot andrológiai ok miatt in vitro fertilisatiós eljáráson átesett betegek alkották. Eredményeink azt mutatják, hogy az endometriosisban szenvedő nők körében szignifikánsan gyakrabban alakul ki a terhesség során praeeclampsia $(\mathrm{p}=0,023)$ és placenta praevia $(\mathrm{p}=0,045)$.

Köpetkeztetések: Vizsgálatunk unikális a bélendometriosis miatt megoperált betegek terhességének és szülésvezetésének vizsgálata kapcsán, ahol a kevés esetszám ellenére hasonló eredményeket kaptunk, mint az eddigi multicentrikus tanulmányok.
\end{abstract}

Orv Hetil. 2019; 160(41): 1633-1638.

Kulcsszavak: bélendometriosis, praeeclampsia, placenta praevia

\section{The effect of surgical treatment of bowel endometriosis on fertility}

Introduction: Bowel endometriosis is when endometrial-like tissue penetrates the bowel serosa, or it reaches the subserous neurovascular plexus. The effect of surgery for colorectal endometriosis on infertility and pregnancy is not fully proven.

Aim: The aim of the present study was to analyse the pregnancy outcome and mode of delivery of patients who underwent 'nerve sparing' anterior resection of the colon.

Method: Between 2009 and 2017, we operated 121 patients with bowel endometriosis, and built up a prospective database where we assessed their wish of pregnancy, the way of the conception, pathologies during pregnancy and mode of delivery.

Statistical analysis: The relationship between endometriosis and pregnancy pathologies was tested by a $\chi^{2}$ probe and Fisher's exact test, additionally the odds ratio (OR) and 95\% confidence interval (CI) were determined. For $\mathrm{p}<0.05$, the result was considered significant.

Results: Out of 121 bowel endometriosis patients, 48 (39.6\%) women got pregnant, 37 (30.5\%) of them with in vitro fertilisation. The control group was built from patients who underwent in vitro fertilisation because of andrological factors. We found that women with endometriosis have a significantly higher risk for praeeclampsia $(\mathrm{p}=0.023)$ and placenta praevia $(\mathrm{p}=0.045)$ during pregnancy.

Conclusions: Our study is a unique description of pregnancy outcome and mode of delivery after surgery for bowel endometriosis, which, despite the small number of cases, has yielded similar results to the previous multicentric studies. 
Keywords: bowel endometriosis, praeeclampsia, placenta praevia

Brubel R, Dobó N, Csibi N, Kövesdi A, Máté Sz, Ács N, Lukovich P, Murber Á, Bokor A. [The effect of surgical treatment of bowel endometriosis on fertility]. Orv Hetil. 2019; 160(41): 1633-1638.

(Beérkezett: 2019. április 24.; elfogadva: 2019. május 24.)

\begin{abstract}
Rövidítések
$\mathrm{BMI}=($ body mass index $)$ testtömegindex $; \mathrm{CI}=($ confidence interval) konfidenciaintervallum; DIE = (deep infiltrating endometriosis) mélyen infiltráló endometriosis; HELLP-szindró$\mathrm{ma}=$ (hemolysis, elevated liver enzymes, low platelet count syndrome) vörösvértestek szétesésével, emelkedett májenzimszinttel és alacsony vérlemezkeszinttel járó szindróma; IEBR = idő előtti burokrepedés; IUGR = (intrauterine growth retardation) méhen belüli növekedési elmaradás; IVF $=($ in vitro fertilisation) szervezeten kívüli megtermékenyítés; OR = (odds ratio) esélyhányados; $\mathrm{PG}=$ prosztaglandin; $\mathrm{TUKEB}=$ Tudományos és Kutatásetikai Bizottság
\end{abstract}

$\mathrm{Az}$ endometriosis egy jóindulatú elváltozás, amelyben endometriumszerú szövet található a méh üregén kívül, elsősorban a hashártyán és/vagy a petefészkekben. A fogamzóképes korban lévő nők 10-15\%-át érinti; vezető tünetei közé tartozik a krónikus kismedencei fájdalom, a dyspareunia (fájdalmas közösülés), a dysmenorrhoea (fájdalmas menstruáció) és az infertilitás [1]. A meddó nók 25-50\%-a érintett a betegség által. A betegek egy része tünetmentes, ezenfelül a betegség súlyossága sem korrelál a tünetek mértékével [2]. Végül azt sem könnyú eldönteni, hogy az adott panaszt valóban endometriosis okozza-e. Klinikailag három megjelenési formája különíthetô el. Peritonealis endometriosis esetében az endometriumszerú szövet a kismedencei hashártyán vagy a petefészkek felszínén helyezkedik el. Másik formája az ovarialis endometriosis, amely csokoládéciszta formájában jelenik meg. Harmadik formája, ha a peritonealis felszín alatt $5 \mathrm{~mm}$-t meghaladó mélységben infiltrál az endometriumszerû szövet, melyet mélyen infiltráló endometriosisnak (DIE) nevezünk: kialakulhat a vastagbélen, a húgyhólyagon vagy bárhol a szervezetben. Ha az endometriosis utóbb említett formája zsír- és fibromuscularis szövettel keveredve a végbél és a hüvely között helyezkedik el, rectovaginalis csomóról beszélünk [3]. Intestinalis érintettséggel a betegek 3-37\%-ában találkozunk [4]; a leggyakrabban a rectumon és a rectosigmoidalis átmenetben fordul elő, ami az összes bélendometrisis $70-93 \%-\mathrm{a}$. Az appendix 2-18\%-ban, a terminalis ileum 2-26\%-ban, illetve a coecum 2\%-ban érintett [4, 5]. Bélendometriosisról beszélünk abban az esetben, ha az endometriumhoz hasonló szövet infiltrálja a bélsubserosát, illetve eléri a subserosus neurovascularis plexust [6]. Amennyiben a folyamat csupán a serosát érinti, peritonealis endometriosisnak tekintjük az elválto- zást $[6,7]$. A genitalis traktuson kívül előforduló endometriosis jellemzője, hogy az érintett szervre specifikus, rendszerint catamenialisan jelentkező tünetekkel jár [8]. A rectumot és a szigmabelet érintő formák dyschesiát és/vagy haematochesiát okozhatnak. Az endometriosis kezelése elsősorban sebészi, célja a tünetek mérséklése és a panaszokat okozó laesiók lehetőség szerinti végleges eradikálása $[6,8]$. A colorectalis DIE mútéti kezelésében a multidiszciplináris megközelítés látszik a legeredményesebbnek az irodalmi adatok alapján $[9,10]$. A vastagbelet érintő mélyen infiltráló endometriosis sebészi kezelésére munkacsoportunk az előzőekben részletesen leírt mútéti technikát alkalmazta [11].

$\mathrm{Az}$ endometriosissal kapcsolatos klinikai kutatás új területe a terhességi kórképek előfordulására kifejtett hatásának és a szülésvezetés módjának vizsgálata. Azt gyanítják, hogy az endometriosis okozhatja vetélés, ectopiás plakkok vérzése, koraszülés, méhen belüli retardáció, praeeclampsia és szülészeti vérzések előfordulását [12]. Az eddigi kutatási adatok ellentmondásosak, Falconer és mtsai azt találták, hogy a praeeclampsia gyakoriságát az endometriosis fokozza, míg a Brosens által vezetett munkacsoport azt találta, hogy endometriosisos nők esetében kisebb gyakorisággal fordul elő terhesség alatt praeeclampsia [13, 14]. A koraszülés, az idő előtti burokrepedés, az elöl fekvő méhlepény az irodalmi adatok alapján gyakrabban figyelhető meg endometriosisban szenvedő nók között $[15,16]$.

$\mathrm{Az}$ endometriosisban érintett betegek gyakrabban küzdenek teherbe esési nehézségekkel, így egy részük csak asszisztált reprodukciós eljárás segítségével tud teherbe esni, ami önmagában egy rizikófaktor terhességi kórképek előfordulása szempontjából [17].

Meddő betegek körében vizsgálták colorectalis endometriosis miatt végzett mưtét után a fájdalom újrakialakulásának gyakoriságát, az életminőséget és a fertilitást. Azt találták, hogy a mútétet követően csökkentek a betegek panaszai, jobb életminőségről számoltak be, a beavatkozás azonban nem minden kétséget kizáróan gyakorolt pozitív hatást a meddőségre [18].

Kevés tanulmány foglalkozik mélyen infiltráló endometriosis miatt mútéten átesett betegek szülésvezetési módjával. Leírták, hogy gyakoribb a császármetszés útján történő szülés, illetve azt is, hogy nincs pozitív korreláció a kettő között. A 'Guideline on the management of women with endometriosis' nem érinti a témát [19]. Egyetlen javaslat áll rendelkezésre, hogy a terhesség be- 
fejezése individuálisan történjen, az adott betegre vonatkoztatva ('Guideline for diagnosis and therapy of endometriosis') [20, 21].

\section{Betegek és módszer}

A Klinikánkon 2009 és 2017 között bélendometriosis miatt végzett idegkímélő anterior reszekción átesett betegek fertilitási adatait vizsgáltuk egy prospektíven létrehozott adatbázis segítségével. A betegek teherbe esési szándékát, módját, annak sikerességét, a terhességi kórképek előfordulását és a szülésvezetés módját tekintettük át. A vizsgálatban szereplő betegeknél az operáló csapat tagjai minden esetben (nőgyógyász, sebész) ugyanazok voltak.

Tekintettel arra, hogy betegeink között nagy számban fordulnak elö IVF-kezelések, kontrollcsoportnak olyan betegeket válogattunk össze, akik andrológiai faktor miatt estek át in vitro fertilisatiós eljáráson teherbe esés céljából $(\mathrm{n}=99)$.

A folytonos változók (életkor, BMI) normáleloszlást mutattak, ezek összehasonlítására t-próbát használtunk. $\mathrm{Az}$ endometriosis és a terhességi kórképek előfordulása közti összefüggést $\chi^{2}$-próbával és Fisher-egzakt teszttel vizsgáltuk, és meghatároztuk az esélyhányadost (OR) és 95\%-os konfidenciaintervallumát (CI). Az eredményt $\mathrm{p}<0,05$ esetén tekintettük szignifikánsnak. Szignifikancia esetén az endometriosis hatását az adott terhességi kórképre többváltozós logisztikus regressziós modellben vizsgáltuk, ahol a terhességi kórképeket befolyásoló egyéb faktorokat is figyelembe vettük (életkor és BMI a szülés idejében, dohányzás a terhesség alatt, többszörös terhesség). Az életkort és a BMI-t egy korábbi tanulmánynak megfelelően kategorikus változókká alakítottuk [22]. A kontrollcsoport és az endometriosisban szenvedők demográfiai adatai megegyeztek, ezért a két csoportot összehasonlíthatónak találtuk.

A vizsgálatot a TUKEB 58242-1/2018/EKU számmal engedélyezte.

\section{Eredmények}

Klinikánkon 121, bélendometriosis miatt megoperált betegből 73-an $(60,3 \%)$ még nem voltak várandósak. Ebből a 73 betegből 37 betegnek $(30,6 \%)$ nem volt aktív gyermekvállalási szándéka a mútétet követően, a fennmaradó $36(29,7 \%)$ betegból 4 esetben sikertelen volt a spontán teherbe eséssel való próbálkozás, 32 betegnél pedig sikertelen volt az in vitro fertilisatiós beavatkozás. A 121 bélendometriosisos betegünk közül így összesen 48-an $(39,6 \%)$ estek teherbe, 37-en (30,5\%) IVF-program segítségével. A 48 betegből 5 betegnél korai vetélés, 2 betegnél pedig késői vetélés zajlott idő előtti burokrepedés miatt, 41 beteg viselte ki a terhességét. A terhességi kórképek közül a következők előfordulását vizsgáltuk: praeeclampsia, HELLP-szindróma, gestatiós diabetes mellitus, cholestasis gravidarum, hypertonia gravidarum, placenta praevia, placenta abruptio, méhen belüli sorvadás (IUGR), idő előtti burokrepedés (IEBR) és a magzatvíz mennyiségbeli eltérése. Betegeinket kétféleképpen hasonlítottuk össze a kontrollcsoporttal.

Az első esetben nem választottuk külön a spontán és az in vitro fertilisatio útján teherbe esett endometriosisos betegeket ( $\mathrm{n}=41 \mathrm{beteg}$ ), és így hasonlítottuk össze őket

1. táblázat | Terhességi kórképek előfordulása az endometriosisban szenvedők (spontán és IVF-program segítségével teherbe esők) és a kontrollcsoport betegei között

\begin{tabular}{|c|c|c|c|c|c|}
\hline Terhességi kórkép & $\begin{array}{l}\text { Endometriosis } \\
(\mathrm{n}=4 \mathrm{l}) \mathrm{n}(\%)\end{array}$ & $\begin{array}{l}\text { Kontrollcsoport } \\
(\mathrm{n}=99) \mathrm{n}(\%)\end{array}$ & p-érték & $\begin{array}{l}\text { Nyers } \\
\text { OR }(95 \% \text { CI })\end{array}$ & $\begin{array}{l}\text { Beállított } \\
\text { OR }(95 \% \mathrm{CI})\end{array}$ \\
\hline Koraszülés & $5(12,2 \%)$ & $26(26,3 \%)$ & 0,068 & $2,564(0,909-7,233)$ & \\
\hline Praeeclampsia & $5(12,2 \%)$ & $2(2,0 \%)$ & 0,023 & $0,148(0,028-0,800)$ & $0,228(0,034-1,523)$ \\
\hline HELLP-szindróma & $0(0 \%)$ & $2(2,0 \%)$ & 0,500 & NA & \\
\hline GDM & $8(19,5 \%)$ & $18(18,2 \%)$ & 0,854 & $0,917(0,363-2,314)$ & \\
\hline Cholestasis grav. & $1(2,4 \%)$ & $1(1,0 \%)$ & 0,501 & $0,408(0,025-6,686)$ & \\
\hline Hypertonia grav. & $4(9,8 \%)$ & $14(14,1 \%)$ & 0,344 & $1,524(0,470-4,940)$ & \\
\hline Placenta praevia & $10(24,4 \%)$ & $11(11,1 \%)$ & 0,045 & $0,388(0,150-1,001)$ & $0,382(0,140-1,046)$ \\
\hline Placenta abruptio & $2(4,9 \%)$ & $4(4,0 \%)$ & 0,568 & $0,821(0,144-4,668)$ & \\
\hline IUGR & $3(7,3 \%)$ & $4(4,0 \%)$ & 0,334 & $0,533(0,114-2,496)$ & \\
\hline IEBR & $8(19,5 \%)$ & $9(9,1 \%)$ & 0,086 & $0,413(0,147-1,158)$ & \\
\hline Magzatvízeltérés & $2(4,9 \%)$ & $13(13,1 \%)$ & 0,125 & $2,948(0,634-13,695)$ & \\
\hline Szülési sérülés & $1(2,4 \%)$ & $0(0,0 \%)$ & 0,293 & NA & \\
\hline Császármetszés & $33(80,5 \%)$ & $81(81,8 \%)$ & 0,854 & $1,091(0,432-2,754)$ & \\
\hline
\end{tabular}

$\mathrm{CI}=$ konfidenciaintervallum; GDM = gestatiós diabetes mellitus; HELLP = vörösvértestek szétesésével, emelkedett májenzimszinttel és alacsony vérlemezkeszinttel járó szindróma; IEBR = idő előtti burokrepedés; IUGR = méhen belüli növekedési elmaradás; IVF = szervezeten kívüli megtermékenyítés; NA = nincs adat; OR = esélyhányados 
2. táblázat | Terhességi kórképek előfordulása az endometriosisban érintettek (IVF-program segítségével teherbe esők) és a kontrollcsoport betegei között

\begin{tabular}{|c|c|c|c|c|c|}
\hline Terhességi kórkép & $\begin{array}{l}\text { Endometriosis } \\
(\mathrm{n}=32) \mathrm{n}(\%)\end{array}$ & $\begin{array}{l}\text { Kontrollcsoport } \\
(\mathrm{n}=99) \mathrm{n}(\%)\end{array}$ & p-érték & $\begin{array}{l}\text { Nyers } \\
\text { OR }(95 \% \mathrm{CI})\end{array}$ & $\begin{array}{l}\text { Beállított } \\
\text { OR ( } 95 \% \mathrm{CI})\end{array}$ \\
\hline Koraszülés & $4(12,5 \%)$ & $26(26,3 \%)$ & 0,082 & $2,493(0,798-7,790)$ & \\
\hline Praeeclampsia & $4(12,5 \%)$ & $2(2,0 \%)$ & 0,031 & $0,144(0,025-0,829)$ & $0,260(0,033-2,041)$ \\
\hline HELLP-szindróma & $0(0 \%)$ & $2(2,0 \%)$ & 0,570 & NA & \\
\hline GDM & $6(18,8 \%)$ & $18(18,2 \%)$ & 0,942 & $0,963(0,346-2,682)$ & \\
\hline Cholestasis grav. & $1(3,1 \%)$ & $1(1,0 \%)$ & 0,430 & $0,316(0,019-5,207)$ & \\
\hline Hypertonia grav. & $2(6,3 \%)$ & $14(14,1 \%)$ & 0,194 & $2,471(0,530-11,512)$ & \\
\hline Placenta praevia & $7(21,9 \%)$ & $11(11,1 \%)$ & 0,124 & $0,446(0,157-1,271)$ & \\
\hline Placenta abruptio & $1(3,1 \%)$ & $4(4,0 \%)$ & 0,814 & $1,305(0,140-12,120)$ & \\
\hline IUGR & $3(9,4 \%)$ & $4(4,0 \%)$ & 0,227 & $0,407(0,086-1,925)$ & \\
\hline IEBR & $7(21,9 \%)$ & $9(9,1 \%)$ & 0,055 & $0,357(0,121-1,054)$ & \\
\hline Magzatvízeltérés & $2(6,3 \%)$ & $13(13,1 \%)$ & 0,236 & $2,267(0,483-10,636)$ & \\
\hline Szülési sérülés & $1(3,1 \%)$ & $0(0,0 \%)$ & 0,244 & NA & \\
\hline Császármetszés & $28(87,5 \%)$ & $81(81,8 \%)$ & 0,455 & $0,643(0,200-2,062)$ & \\
\hline
\end{tabular}

$\mathrm{CI}=$ konfidenciaintervallum; GDM = gestatiós diabetes mellitus; HELLP = vörösvértestek szétesésével, emelkedett májenzimszinttel és alacsony vérlemezkeszinttel járó szindróma; IEBR = idő elôtti burokrepedés; IUGR = méhen belüli növekedési elmaradás; IVF = szervezeten kívüli megtermékenyítés; $\mathrm{NA}=$ nincs adat; $\mathrm{OR}$ = esélyhányados

az in vitro fertilisatióval teherbe esett egészséges nők csoportjával ( $\mathrm{n}=99$ beteg). Eredményeink azt mutatják, hogy a praeeclampsia $(\mathrm{p}=0,023)$ és a placenta praevia $(\mathrm{p}=0,045)$ szignifikánsan gyakoribb endometriosisos betegek körében, mint a kontrollcsoportban (1. táblázat). Ezzel szemben ha a terhességi kórképeket befolyásoló egyéb faktorokat is figyelembe vettük (életkor és BMI a szülés idejében, dohányzás a terhesség alatt, többszörös terhesség), ezen terhességi kórképek szignifikanciája megszűnt. Ezenkívül a szülésvezetés módját is vizsgáltuk, hányan szültek per vias naturales (hüvelyi úton) vagy császármetszés segítségével. Előfordult-e koraszülés vagy szülési sérülés. Az általunk vizsgált betegcsoportban nem fordult elő gyakrabban koraszülés $(\mathrm{p}=0,068)$ vagy császármetszés $(\mathrm{p}=0,854)$, mint a kontrollcsoportban (1. táblázat).

A következő lépésben csak azokat a betegeket hasonlítottuk össze a kontrollcsoporttal, akik IVF-program segítségével estek teherbe $(\mathrm{n}=32$ beteg). Ebben az esetben a praeeclampisa $(\mathrm{p}=0,031)$ szignifikánsan gyakrabban fordult elő (2. táblázat). Ha a fent említett, a terhesség lefolyását potenciálisan negatívan befolyásoló tényezőktől függetlenítettük adatainkat, úgy a szignifikancia megszû́nt. A koraszülés és a császármetszés gya-

3. táblázat $\mid A z$ endometriosisban szenvedók és a kontrollcsoport betegeinek demográfiai adatai

\begin{tabular}{llll}
\hline Demográfiai adat & Endometriosis & Kontrollcsoport & p-érték \\
\hline Életkor $(e ́ v)$, átlag \pm SD & $33,7 \pm 3,7$ & $34,6 \pm 3,6$ & 0,236 \\
BMI $\left(\mathrm{kg} / \mathrm{m}^{2}\right)$, átlag \pm SD & $26,4 \pm 5$ & $27,4 \pm 2,6$ & 0,25 \\
\hline
\end{tabular}

$\mathrm{BMI}=$ testtömegindex $; \mathrm{SD}=$ standard deviáció korisága ebben az összehasonlításban sem különbözött szignifikánsan (2. táblázat).

A szülésvezetés módját tekintve nem találtunk eltérést. A 41 betegből 8 beteg szült hüvelyi úton, egy betegnél fordult elő szülési sérülés, amely azonban nem érintette a végbél záróizomzatát.

$\mathrm{Az}$ endometriosis és a kontrollcsoport életkora és BMI-je nem különbözött egymástól szignifikánsan (3. táblázat).

\section{Megbeszélés}

Előzetes vizsgálatok számos terhességi kórkép előfordulását igazolták endometriosis miatt megoperált betegek várandóssága alatt. Az általunk vizsgált betegcsoport az összes endometriosisos eset kis hányadát foglalja magában, azonban igen radikális mútéti beavatkozáson estek át, ami önmagában is számos szövődményt vonzhat maga után.

Betegeink között a praeeclampsiát találtuk szignifikánsan gyakrabban előfordulónak bélendometriosis miatt megoperált nők esetében. Az endometriosisnak a praeeclampsia előfordulására kifejtett hatásának vizsgálata még mindig nem tisztázott. Brosens és mtsai úgy találták, hogy az esély praeeclampsia kialakulására endometriosis talaján lehet fokozott, csökkent vagy változatlan [23]. Számos tanulmány igazolta, hogy endometriosisban szenvedő nook terhessége alatt gyakrabban fordul elő praeeclampsia [22, 23]. Szintén a Brosens által vezetett munkacsoport írta le, hogy a praeeclampsia a junkcionális zóna spirális artériái malformációjának és a kóros platentációnak a talaján alakulhat ki [24]. Kimutatták továbbá azt is, hogy az endometriosis károsíthatja a junkci- 
onális zónát, ami a két kórkép kapcsolatát is igazolná [25].

Eredményeink alapján betegeink között gyakrabban fordult elő placenta praevia, amit számos más tanulmány is hasonlóképpen írt le [22, 26-28]. Endometriosisban szenvedő nók esetében megváltozik a méh kontrakcióinak frekvenciája és amplitúdója, ami befolyásolhatja az embrió transzportját és beágyazódását [29]. A méh ezen kóros perisztaltikája is magyarázhatja endometrioisban a placenta praevia gyakoribb előfordulását [16]. Leírták továbbá, hogy nagyobb arányban fordul elő placenta praevia olyan betegek körében, akik mélyen infiltráló rectovaginalis endometriosisban szenvednek [16]. Ezen túlmenően, endometriosisos nők körében tízszer gyakoribb a placenta praevia, mint egészséges nők körében [16].

A 2016-ban, a Linzi Egyetemen végzett tanulmány nem igazolt összefüggést a mélyen infiltráló endometriosis miatt megoperált betegek és az említett terhességi kórképek előfordulása között [21]. Úgy találták, hogy nagyobb eséllyel szülnek ezen nők császármetszés útján, amit korábban már Stephansson és mtsai is leírtak [22]. Vizsgálataink során nem találtunk szignifikáns különbséget a császármetszés gyakoriságában az endometriosisban szenvedő betegek és a kontrollcsoport között. Az asszisztált reprodukció segítségével teherbe esett nők gyakrabban kérik császármetszés elvégzését a fájdalom miatti félelem vagy a fokozott anyai aggodalom miatt. Magyarországon 2018-ban az átlagos császármetszési ráta körülbelül $50 \%$ volt; tanulmányunkban az endometriosis- és a kontrollcsoport betegeinek is közel a $80 \%$-a szült császármetszés segítségével. Remzi és mtsai vizsgálataik során úgy találták, hogy azon betegek körében, akik 'ileal pouch'-analis anastomosis mútéten estek át, majd később spontán hüvelyi úton szültek, szignifikánsan gyakrabban fordult elő a musculus sphincter ani sérülése [30]. Egy Olaszországban végzett felmérés alapján leírták, hogy a hüvelyi szülés kedvezően hat a dysmenorrhoeára és az endometriosis újrakiújulására. Azok a nők, akik spontán hozták világra gyermeküket, szülés után hosszabb ideig voltak panaszmentesek, mint a császármetszés segítségével szülők [31]. Mivel ezt a post partum időszakot nem vizsgáltuk tanulmányunkban, erről a saját adataink hiányosak.

A szülés folyamán biokémiai folyamatok sorozata zajlik, mind terminusközelben történő szülés, mind koraszülés esetén. Idetartozik a proinflammatoricus mediátorok, mint például a $\mathrm{PGE}_{2}$, a ciklooxigenáz-2 vagy az interleukin-8 aktiválódása [32]. Az ennek eredményeképpen létrejövő lokális és szisztémás gyulladás fokozza a myometrium kontraktilitását és a cervix érését. Endometriosisban szenvedő nők között több nemkívánatos változás történik a periimplantációs időszakban és a terhesség folyamán. Idetartozik az endometrium rezisztenciája a szelektívprogeszteron-hatásokkal szemben, valamint gyulladásos folyamatok kialakulása az emelkedett PG- és citokinszintek miatt a méhnyálkahártyában. Ezen túlmenően inadekvát méhkontraktilitás alakul ki [29, 33, 34]. Mindezen változásokat leírták olyan nők esetében is, akiknél gyakrabban figyelhettünk meg koraszülést, méhen belüli sorvadást vagy a placenta rendellenességeit [35, 36]. Más, krónikus gyulladással járó betegségek - mint a Crohn-betegség vagy a rheumatoid arthritis - is gyakran társulnak koraszüléssel [37, 38].

Eredményeink - tekintettel az alacsony esetszámra további betegek bevonását és vizsgálataink bővítését teszik szükségessé.

\section{Következtetés}

Elmondhatjuk, hogy a terhességi kórképeket befolyásoló egyéb faktorokat is figyelembe véve (életkor és BMI a szülés idejében, dohányzás a terhesség alatt, többszörös terhesség) a terhességi kórképek nem fordulnak elő szignifikánsan gyakrabban bélendometriosis miatt megoperált betegek körében.

Ma Magyarországon több mint 200000 nő szenved endometriosisban; ezen betegek megfelelő terhesgondozására és szülésvezetésére van szükségünk, a nem kívánt terhességi kórképek és komplikációk elkerülése céljából.

Anyagi támogatás: A cikk a Bolyai János Kutatási Ösztöndíj és az Emberi Erőforrások Minisztériuma ÚNKP18-4 kódszámú új nemzeti kiválóság programjának támogatásával készült.

Szerzői munkamegosztás: B. R.: Endometriosisban szenvedő betegek elektronikus adatbázisának szerkesztése, andrológiai faktor miatt asszisztált reprodukciós eljárásban részt vevő betegek elektronikus adatbázisának szerkesztése, statisztikai analízis. Cs. N., M. Sz., D. N.: Endometriosisban szenvedő betegek elektronikus adatbázisának szerkesztése. K. A.: Statisztikai analízis. Á. N.: A közlemény átfogó szakmai értékelése. M. Á.: Andrológiai faktor miatt asszisztált reprodukciós eljárásban részt vevő betegek elektronikus adatbázisnának szerkesztése. L.P., B. A.: A betegek koordinálása, a közlemény szakmai elemzése. A cikk végleges változatát valamennyi szerző elolvasta és jóváhagyta.

Érdekeltségek: A szerzőknek nincsenek érdekeltségeik.

\section{Irodalom}

[1] Giudice LC, Kao LC. Endometriosis. Lancet 2004; 364: 17891799.

[2] Roman H, Sanguin S, Puscasiu L. Medical treatment of endometriosis: an obligation rather than a mere option! Gynecol Obstet Fertil. 2012; 40: 320-325.

[3] Meuleman C, D'Hoore A, Van Cleynenbreugel B, et al. Outcome after multidisciplinary $\mathrm{CO}_{2}$ laser laparoscopic excision of deep infiltrating colorectal endometriosis. Reprod Biomed Online 2009; 18: 282-289. 
[4] Coronado C, Franklin RR, Lotze EC, et al. Surgical treatment of symptomatic colorectal endometriosis. Fertil Steril. 1990; 53: 411-416.

[5] Zwas FR, Lyon DT. Endometriosis. An important condition in clinical gastroenterology. Dig Dis Sci. 1991; 36: 353-364.

[6] Remorgida V, Ferrero S, Fulcheri E, et al. Bowel endometriosis: presentation, diagnosis, and treatment. Obstet Gynecol Surv 2007; 62: 461-470.

[7] Chapron C, Fauconnier A, Vieira M, et al. Anatomical distribution of deeply infiltrating endometriosis: surgical implications and proposition for a classification. Hum Reprod. 2003; 18: 157-161.

[8] Kennedy S, Bergqvist A, Chapron C, et al. ESHRE guideline for the diagnosis and treatment of endometriosis. Hum Reprod. 2005; 20: 2698-2704.

[9] Dousset B, Leconte M, Borghese B, et al. Complete surgery for low rectal endometriosis: long-term results of a 100-case prospective study. Ann Surg. 2010; 251: 887-895

[10] Meuleman C, Tomassetti C, Wolthuis A, et al. Clinical outcome after radical excision of moderate-severe endometriosis with or without bowel resection and reanastomosis: a prospective cohort study. Ann Surg. 2014; 259: 522-531.

[11] Bokor A, Brubel R, Lukovich P, et al. Experience with multidisciplinary laparoscopic surgery in patients with deep infiltrating colorectal endometriosis. [Mélyen infiltráló colorectalis endometriosis miatt végzett multidiszciplináris laparoszkópos mútétek során szerzett tapasztalataink.] Orv Hetil. 2014; 155: 182-186. [Hungarian]

[12] Vigano P, Corti L, Berlanda N, et al. Beyond infertility: obstetri$\mathrm{cal}$ and postpartum complications associated with endometriosis and adenomyosis. Fertil Steril. 2015; 104: 802-812.

[13] Brosens IA, De Sutter P, Hamerlynck T, et al. Endometriosis is associated with a decreased risk of preeclampsia. Hum Reprod. 2007; 22: 1725-1729.

[14] Falconer H. Pregnancy outcomes in women with endometriosis. Semin Reprod Med. 2013; 31: 178-182.

[15] Conti N, Cevenini G, Vannuccini S, et al. Women with endometriosis at first pregnancy have an increased risk of adverse obstetric outcome. J Matern Fetal Neonatal Med. 2015; 28: 17951798.

[16] Vercellini P, Parazzini F, Pietropaolo G, et al. Pregnancy outcome in women with peritoneal, ovarian and rectovaginal endometriosis: a retrospective cohort study. BJOG 2012; 119: 15381543.

[17] Helmerhorst FM, Perquin DA, Donker D, et al. Perinatal outcome of singletons and twins after assisted conception: a systematic review of controlled studies. BMJ 2004; 328: 261.

[18] Stepniewska A, Pomini P, Scioscia M, et al. Fertility and clinical outcome after bowel resection in infertile women with endometriosis. Reprod Biomed Online 2010; 20: 602-609.

[19] ESHRE Endometriosis Guideline Development Group. Management of women with endometriosis. Geburtsh Frauenheilkd. 2013

[20] Ulrich U, Buchweitz O, Greb R, et al. Interdisciplinary S2k guidelines for the diagnosis and treatment of endometriosis. Geburtshilfe Frauenheilkd. 2013; 73: 890-898.

[21] Allerstorfer C, Oppelt P, Enzelsberger SH, et al. Delivery after operation for deeply infiltrating endometriosis. Biomed Res Int. 2016; 2016: 8271452.
[22] Stephansson O, Kieler H, Granath F, et al. Endometriosis, as sisted reproduction technology, and risk of adverse pregnancy outcome. Hum Reprod. 2009; 24: 2341-2347.

[23] Brosens I, Brosens JJ, Fusi L, et al. Risk of adverse pregnancy outcome in endometriosis. Fertil Steril. 2012; 98: 30-35.

[24] Brosens IA, Robertson WB, Dixon HG. The role of the spiral arteries in the pathogenesis of preeclampsia. Obstet Gynecol Annu. 1972; 1: 177-191.

[25] Leyendecker G, Kunz G, Herbertz M, et al. Uterine peristaltic activity and the development of endometriosis. Ann N Y Acad Sci. 2004; 1034: 338-355.

[26] Shmueli A, Salman L, Hiersch L, et al. Obstetrical and neonatal outcomes of pregnancies complicated by endometriosis. J Matern Fetal Neonatal Med. 2018; 32: 845-850.

[27] Zullo F, Spagnolo E, Saccone G, et al. Endometriosis and obstetrics complications: a systematic review and meta-analysis. Fertil Steril. 2017; 108: 667-672.e5.

[28] Exacoustos C, Lauriola I, Lazzeri L, et al. Complications during pregnancy and delivery in women with untreated rectovaginal deep infiltrating endometriosis. Fertil Steril. 2016; 106: 11291135.el.

[29] Aguilar HN, Mitchell BF. Physiological pathways and molecular mechanisms regulating uterine contractility. Hum Reprod Update 2010 ; 16: 725-744.

[30] Remzi FH, Gorgun E, Bast J, et al. Vaginal delivery after ileal pouch-anal anastomosis: a word of caution. Dis Colon Rectum 2005; 48: 1691-1699.

[31] Bulletti C, Montini A, Setti PL, et al. Vaginal parturition decreases recurrence of endometriosis. Fertil Steril. 2010; 94: 850855.

[32] Smith R. Parturition. N Engl J Med. 2007; 356: 271-283.

[33] Burney RO, Talbi S, Hamilton AE, et al. Gene expression analysis of endometrium reveals progesterone resistance and candidate susceptibility genes in women with endometriosis. Endocrinology 2007; 148: 3814-3826.

[34] Gentilini D, Perino A, Viganò P, et al. Gene expression profiling of peripheral blood mononuclear cells in endometriosis identifies genes altered in non-gynaecologic chronic inflammatory diseases. Hum Reprod. 2011; 26: 3109-3117.

[35] Kunz G, Beil D, Huppert P, et al. Structural abnormalities of the uterine wall in women with endometriosis and infertility visualized by vaginal sonography and magnetic resonance imaging. Hum Reprod. 2000; 15: 76-82.

[36] Fernando S, Breheny S, Jaques AM, et al. Preterm birth, ovarian endometriomata, and assisted reproduction technologies. Fertil Steril. 2009; 91: 325-330.

[37] Skomsvoll JF, Ostensen M, Irgens LM, et al. Obstetrical and neonatal outcome in pregnant patients with rheumatic disease. Scand J Rheumatol Suppl. 1998; 107: 109-112.

[38] Nørgård B, Pedersen L, Christensen LA, et al. Therapeutic drug use in women with Crohn's disease and birth outcomes: a Danish nationwide cohort study. Am J Gastroenterol. 2007; 102: 1406-1413.

(Brubel Réka dr., Székelyszabar, Hunyadi u. 7., 7737 e-mail: brubelreka@gmail.com) 